\title{
Hava Sporları Turizmi ve Safranbolu'nun Hava Sporları Potansiyelinin Belirlenmesi
}

\author{
Oğuz Dikera*, Adnan Çetinkaya ${ }^{\mathrm{b}}$, Ahmet Cinkarac \\ ${ }^{a}$ Karabük Üniversitesi Turizm Fakültesi, Karabük \\ b,cKarabük Üniversitesi Safranbolu Meslek Yüksekokulu, Karabük
}

\begin{abstract}
$\ddot{O} z$
Destinasyonlardaki konaklama sürelerinin uzatılması, turistik ürünün çeşitlendirilmesi ve mevcut kaynakların korunması için alternatif turizm faaliyetlerinin geliştirilmesi, turizm endüstrisinde önem arz etmektedir. Bu görüșten hareketle birçok farkh faaliyet alternatif turizm kapsamında değerlendirilmektedir. Spor turizmi ve hava sporları turizmi söz konusu faaliyetlere örneklerdir. Bu çalı̧ma kapsamında spor turizmi ve hava sporları turizmi kavramları incelenmiş, dünyada ve Türkiye'deki mevcut durumları tespit edilmiştir. Bunun yanı sıra çalışma kapsamında Safranbolu turizm destinasyonunun hava sporları ile ilgili potansiyeli değerlendirilerek, bölge için alternatif bir turizm önerisi sunulmuştur.
\end{abstract}

Anahtar Kelimeler: Spor Turizmi, Hava Sporları, Hava Sporları Turizmi, Safranbolu Turizm Destinasyonu.

\section{Air Sports Tourism and Determination of Safranbolu's Air Sports Potential}

\section{Abstract}

Promotion of new touristic activities in an attempt to extension of accommodation periods, diversification of tourism products, protection of current touristic resources become more of an issue in tourism literature. From this point of view, various activities are evaluated within the context of tourism. Sport tourism and air sports' tourism are two cases in point. Within the scope of this work, the terms of sport tourism and air sports tourism have been evaluated with current situations in world and in Turkey. Additionally, Safranbolu tourism destination has been evaluated in terms of its air sports tourism potential and some suggestions have been made for an alternative tourism type.

Keywords: Sport Tourism, Air Sports, Air Sports Tourism, Safranbolu Tourism Destination.

\section{Gírìs}

Turizm cazibelerini oluşturan unsurlar üzerinde kitle turizmi ile başlayan yıpranma süreci, söz konusu kaynakların gelecek kuşaklara aktarımı noktasında kayg1 yaratacak boyutlara ulaşmıştır. Bu kaygılar neticesinde koruma odaklı pek çok öneri geliştirilerek bir yandan turizm kaynaklarının yoğun kullanımının normalleştirilmesi, diğer yandan turizme olan talebin azalmasının önlenmesine çalışılmıştır. Bu bağlamda alternatif turizm kavramı ortaya çıkmıştır. Alternatif turizm ile yoğun talebin olduğu turizm destinasyonlarında, farklı turizm türleri geliştirilerek kaynakların dengeli kullanımı amaçlanmaktadır. Alternatif turizm kavramı kapsamında farklı alt yapı ve fiziki özellikler çerçevesinde birçok turizm çeşidi ortaya konulmuştur. 
Söz konusu turizm çeşitlerinden birisi de spor turizmidir. Bu turizm çeşidi, aktivitelerin turizm faaliyetleri kapsamında gerçekleştirilmesi şeklinde ifade edilmektedir. Spor turizmi kapsamında incelenen faaliyetlerin dünya genelinde en çok rağbet görenlerinden biri ise hava sporları olarak adlandırılan aktiviteler çerçevesinde gelişen turizm tipidir. Ülkemizde son yillarda popüler hale gelen söz konusu faaliyetlerden Kapadokya turizm destinasyonunda gerçekleştirilen sıcak hava balonu, Ölüdeniz turizm destinasyonunda gerçekleştirilen yamaç paraşütü faaliyetleri bu kapsamda değerlendirilebilir. Bunun yanında Birleşmiş Milletler Dünya Turizm Örgütü ile Kültür ve Turizm Bakanlığı tarafından kabul edilen ve söz konusu faaliyetler kapsamında değerlendirilen; mikrolayt, model uçak, delta kanat gibi birçok aktivite hava sporları kapsamında ülkemizde turizm faaliyetleri kapsamında gerçekleştirilmektedir.

Bu bağlamda söz konusu turizm çeşidine konu olan faaliyetlerin tanımlanması, mevcut durumun tespit edilmesi, dünyadaki örneklerinin aktarılması ile faaliyetlerin gerçekleşmesi için ihtiyaç duyulan altyapı şartlarının belirlenmesi söz konusu turizm çeşidinin uygulanabilirliğinin ortaya konulmasını sağlayacaktır. Bu çalışma kapsamında hava sporları turizmi kavramı incelenerek, Safranbolu destinasyonu için uygunluğu belirlenmeye çalışılacaktır.

\section{SPOR TURIZMI}

İnsanları turizm faaliyetlerine katılmaya yönelten genelde güdülerin doyurulması istekliliğidir (Gnoth, 1997: 283). Turizm davranışı, söz konusu güdülerin doyurulması için bir amaç olduğu gibi, çeşitli amaçlara ulaşabilmek için bir araç görevi de görebilir (Doğan, 2004: 6). Başka bir ifadeyle turizm her zaman bir amaç olarak değil kimi zaman da insanların alternatif faaliyetler ya da amaçlara ulaşmasında araç olarak karşımıza çıkmaktadır. Tüm bu alternatif faaliyetler "alternatif turizm” kavramı içerisinde incelenmektedir.

Alternatif turizm; çevreye saygıll, doğal kaynakları koruyan, yerel halkın kazanımlarını azaltmaksızın turizm faaliyetleri nedeniyle meydana gelen olumsuzlukları azaltan ve kitle turizminin klasik türlerine tepki olarak ortaya çıkan turizm faaliyetlerine verilen addır (Albayrak, 2013: 39). Alternatif turizm faaliyetlerinde ana güdü arzulanan faaliyete ulaşmak olduğundan turizm bu noktada aracılık etmektedir. Gerekçesi olan faaliyetlerin adları ile anılan alternatif turizme tipleri temel bir sınıflandırma ile şu şekilde sıralanabilir (Öztürk ve Yazıcıŏlu, 2002: 184);

- Kongre Turizmi

- Golf Turizmi

- Spor Turizmi

- Macera Turizmi

- Kültür Turizmi

- Eko Turizm 
- Termal Turizm

- Gençlik Turizmi

Söz konusu alternatif turizm çeşitleri genellikle tek boyutludur. Fakat spor turizmi birden çok boyutu olması ile diğerlerinden ayrılmaktadır. Özellikle spor aktivitelerinin çeşitliliği, yeni spor aktivite türlerinin sürekli çoğalması ile spor turizmi birçok faaliyeti bünyesinde barındıran bir alternatif turizm çeşididir.

Tablo 1. Tarihsel Dönemlerine Göre Popüler Olan Spor Dalları

\begin{tabular}{|c|l|}
\hline Dönem & Spor Çeşidi \\
\hline 1800 öncesi & At yarışı, golf, kriket, boks, kürek, eskrim \\
\hline $1820-30$ & Atıcılı, yelkenli \\
\hline $1840-60$ & Beyzbol, futbol, yüzme \\
\hline $1860-70$ & Atletizm, kayak, bisiklet, kano yarışı \\
\hline $1870-80$ & Amerikan futbolu, çim tenisi, hokey, badminton \\
\hline $1880-1900$ & $\begin{array}{l}\text { Buz hokeyi, jimlastik, basketbol, voleybol, bovling, masa tenisi, halter, buz } \\
\text { pateni }\end{array}$ \\
\hline 1900 sonrası & Hentbol, duvar tenisi, karate, aikido, tekvando \\
\hline
\end{tabular}

Kaynak: Yavaş, 2005: 8.

En basit anlamı ile spor turizmi, katılımcılarının en az 24 saat süreli konaklama ile seyahatlerinde öncelikli güdünün sportif faaliyetlere katılmak olduğu, ziyaret edilen yerin ikincil öncelikli olarak değerlendirildiği turizm çeşididir (Gibson, 1998a: 48). Bir başka tanımla spor turizmi, spor faaliyetlerine katılmak amacıyla turizmin kullanılması durumunda ortaya çıan turizm şekline verilen addır (Kurtzman, 2005: 15). Spor turizmi ile ilgili farklı bir tanımda ise; spor kültürü ile ilgili destinasyonlara yönelik insanların ticari olmayan nedenler ile gerçekleştirdikleri seyahatler ifadesi kullanılmaktadır (Pigeassou, 2004: 287).

Tablo 2. Spor Turizmi ve Turizm Sporu Kavramları

\begin{tabular}{|c|c|}
\hline \multirow[t]{5}{*}{$\begin{array}{l}\text { Spor } \\
\text { Turizmi }\end{array}$} & $\begin{array}{l}\text { Ticari olmayan nedenler ile spor faaliyetlerini gözlemlemek için sürekli yaşanan } \\
\text { yerin dişına yapılan seyahatler (Hall, 1992) }\end{array}$ \\
\hline & $\begin{array}{l}\text { Açık alan, kapalı alan, yapay zemin, doğal zemin fark etmeksizin cezbedici spor } \\
\text { faaliyetleri için bir bölgede bulunan insanların boş zamanlarındaki davranışlarının } \\
\text { ifade ediliş şekline verilen addır (Ruskin, 1987). }\end{array}$ \\
\hline & $\begin{array}{l}\text { Bir spor faaliyetine yönelik olarak izleyici ya da katılımcı olarak yapılan tatil (Weed } \\
\text { ve Bull, 1997). }\end{array}$ \\
\hline & $\begin{array}{l}\text { İnsanların sürekli yaşadıkları yerlerin dışına seyahat etmelerine neden olan, fiziksel } \\
\text { faaliyetlere katılma, fiziksel aktiviteleri izleme ya da faaliyetlerde bulunma ile ilgili } \\
\text { güdüler çerçevesinde gelişen serbest zaman temelli seyahatlerdir (Gibson, 1998). }\end{array}$ \\
\hline & $\begin{array}{l}\text { Sürekli yaşanan ya da iş hayatının sürdüğü yerin dişına, ticari olmayan amaçlarla } \\
\text { organize ya da bireysel aktif veya pasif sporun bütün çeşitlerine katılmak için } \\
\text { yapılan seyahatlerdir (Standeven ve DeKnop, 1999). }\end{array}$ \\
\hline $\begin{array}{l}\text { Turizm } \\
\text { Sporu }\end{array}$ & $\begin{array}{l}\text { Sürekli yaşadığı yerlerin dışına seyahat eden, aktif ya da pasif olarak spor } \\
\text { aktivitelerine katılımı ikinci planda tutan seyahatlerdir (Gammon ve Robinson, } \\
\text { 1997). }\end{array}$ \\
\hline
\end{tabular}

Kaynak: Hinch ve Higman, 2001: 49' dan uyarlanmıştır. 
Tanımlardan da anlaşıldığı üzere spor turizmi, spor faaliyetleri kapsamında turizme katılım ya da turizm faaliyetleri kapsamında yapılan spor aktivitelerine katılma şeklinde gerçekleşmektedir. Bu bağlamda spor turizmi katılımcıları üç grupta incelenir; (a)spor olayları seyircileri, (b)sporla ilişkili faaliyetler için seyahat edenler ve (c)spor faaliyetleri katılımcılarıdır (Gibson, 1998b: 156). Hangi türde faaliyete katılırsa katılsın yukarıdaki faaliyetlere katılmak amacıyla seyahat eden bütün turistler spor turisti olarak adlandırılır. Spor turizmi faaliyetleri geçmişten günümüze dönemin popüler sporları ile birlikte anılmakta ve yürütülmektedir.

Tablo 3. Spor Turizmi Kategorileri ve Tipleri

\begin{tabular}{|l|l|}
\hline Spor Turizmi Kategorileri & Faaliyet Tipleri \\
\hline Sportif Cazibelerin Ziyaretleri & - Dağlar \\
& - Spor Miras Alanları (Ragbi birliğinin doğum \\
& yeri, Rugby Birleşik Krallık ) \\
& - Spor Müzeleri \\
& - Spor Statları \\
& - Spor Temalı Parklar \\
& - Kiymetli Spor Tesisleri \\
\hline Spor Tesisleri Ziyaretleri & - Kiş Sporları Tesisleri \\
& - Yaz Sporları Tesisleri \\
\hline Spor Organizasyonlarına Katılım & - Spor, Sağlık Tesisleri \\
& - Spor Hazırlık Tesisleri \\
\hline Doğa ve Macera Sporlarına Katılımı & faaliyetleri (Olimpiyat Oyunları, Futbol \\
& Müsabakaları vb.) \\
\hline & - Rafting ve Dalış Sporu \\
& - Tisiklet Turları \\
& - Kayak Sporları \\
& - Golf Sporları \\
\hline
\end{tabular}

Kaynak: Ritchie ve Adair, 2002: 4'den uyarlanmıştır.

Türkiye Seyahat Acentaları Birliğinin (TÜRSAB) raporuna göre spor turizmi dünya genelinde toplam turizm gelirleri içerisinde 180 milyar dolarlık bir büyüklüğe sahiptir. Küresel turizmin 2014 yılı için büyüme oranı yüzde 4-5 seviyelerinde iken spor turizmi yıllık bazda yüzde 14 büyüme kaydetmiştir. Konu ile ilgili bir başka bilgiye göre TÜRSAB spor turistlerinin normal turistlerden yaklaşık iki misli fazla harcama yaptığını vurgulamaktadır (TÜRSAB, 2015: 2-3).

Ülkemizde de dünya piyasasına paralel olarak özellikle 1990'lı yıllardan sonra sportif aktiviteler turizm faaliyetleri içinde daha geniş bir yer tutmuş, özellikle doğa sporlarının yapıldığı spor turizmi kayda değer bir hızla gelişmiştir. Nitelikli spor turizmi ile sportif etkinlikler güçlü organizasyonlar aracılığı ile ülkemizde yaygınlaştırılmıştır (Koçan, 2007: 31). 
Tablo 4. Yıllara Göre Ülkemizdeki Spor Turizm İstatistikleri

\begin{tabular}{|c|c|c|c|}
\hline Y11 & $\begin{array}{c}\text { Toplam Turist } \\
\text { Sayıs1 }\end{array}$ & $\begin{array}{c}\text { Sportif Faaliyet Amaciyla } \\
\text { Gelen Turist Sayıs }\end{array}$ & $\begin{array}{c}\text { Sportif Amaçla Gelenlerin } \\
\text { Toplamdaki Payı (\%) }\end{array}$ \\
\hline 2003 & 16.302 .053 & 156.499 & 0.96 \\
\hline 2008 & 30.979 .979 & 319.093 & 1.03 \\
\hline 2012 & 36.776 .645 & 551.649 & 1.5 \\
\hline 2014 & 36.837 .900 & 552.568 & 1.4 \\
\hline
\end{tabular}

Kaynak: TÜRSAB, 2015: 4

Tablo 4'te görüldüğü üzere spor turizmi amaciyla seyahat edenlerin toplam ziyaretçiler içerisindeki oranı yıllara göre artış göstermektedir. Özellikle 2014 yılı içerisinde 550 binin üzerinde yabancı turist Türkiye'ye sportif faaliyet amaçlı ip 900 milyon doların üzerinde harcama yapmıştır. Bu sayı toplam turist sayısı içerisinde yüzde 1.4'lük bir orana tekabül etmektedir (TÜRSAB, 2015: 3). Spor turizminin geliştirilmesi ve faaliyetlerin gerçekleştirilerek pastadan payın arttırılması ülke turizmi açısından önem arz etmektedir. Böylece hem turizm gelirlerinde bir artış sağlanacak hem de spor turizminin olumlu etkilerinden faydalanılacaktır. Ross (2001) spor turizminin destinasyona ve endüstriye faydalarını şu şekilde sıralamaktadır;

- Kültürel etkileşimi sağlar.

- Turizm talebinin tüm yıla yayılmasına katkıda bulunur.

- Turistik ürünü çeşitlendirir.

- Farklı turizm çeşitleri ile etkileşimle bulunarak turizmin çeşitlenmesini sağlar (sualtı fotoğrafçlığı, hava fotoğrafçılığı gibi ).

- Konaklama sürelerinin uzamaya neden olur.

Görüldüğü üzere gerek ekonomik gerekse sektörel ve kültürel nedenler spor turizminin önemsenmesi gerektirmektedir. Destinasyonun özelliklerine göre uygun spor faaliyetlerinin tespit edilerek ilgili turizm faaliyetlerinin geliştirilmesi önemlidir.

Ülkemizde spor turizmi faaliyetleri içerisinde en önemlileri; golf turizmi, futbol turizmi, su sporları ve hava sporları turizmidir. Söz konusu spor turizmi çeşitlerinden belki de faaliyet bakımından en zengin ve alt yapı bakımından en uygun olanlarından birisi hava sporları turizmidir.Şöyle ki; golf turizminde (cross golf hariç) 1lıman iklimlerde yeşil arazilere ihtiyaç duyulmaktadır. Futbol turizmi için geniş tesisler gerekli iken su altı sporları turizmi için dalışa uygun deniz ya da göllere ihtiyaç bulunmaktadır. Fakat hava sporları turizmi destinasyon için diğer çeşitlerden daha fazla uygundur. Diğer yandan gelişmekte olan bir turizm biçimi olması da hava sporları turizmine yönelmede önemlidir. Bu bağlamda söz konusu turizm türünün incelenmesi faydalı olacaktır. 


\section{HAVA SPORLARI TURIZMI}

Spor turizmi çeşitlerinden biri olan hava sporları turizmi günümüzde gittikçe önemini arttırmakta olan bir turizm türüdür. Hava sporlarının temeli kişinin çeşitli teknik malzemeleri kullanarak ve havada meydana gelen değişimlerden yararlanarak gökyüzünde hareket etmesine dayanmaktadır (Albayrak, 2013: 190).

Bilindiği gibi hava sporları hava araçları ile gerçekleştirilmektedir. Hava araçları; havalanabilen ve havada seyredebilme kabiliyetine sahip her türlü araca verilen isimdir (THK, 2015: 9).

$\mathrm{Bu}$ bilgiler ışığında hava sporları turizmi şu şekilde tanımlanabilir; ticari amaç gütmeksizin sürekli yaşanan ve çalışılan yerin dışına hava araçlarından biri ya da birden fazlası ile birlikte yapılan sportif faaliyetlere katılmak, izlemek ya da organizasyonlara katılmak için gerçekleştirilen seyahatlerdir. Tanım söz konusu kavramın spor turizminin bir çeşidi olması nedeniyle spor turizmi tanımlarında bahsedilen " spor faaliyeti" kısmına hava araçları ile yapılan sportif faaliyetler ibaresi eklenerek oluşturulmuştur. Burada ifade edilmek istenen ticari amaçlar dışında kalan bütün amaçlar ve havacılık sporlarının herhangi bir türüne, izleyici, yarışmacı ya da katılımcı olarak katılma güdüsü ile yapılan seyahatlerdir. Bu faaliyetlere katılan kişiler ise hava sporları turisti olarak adlandırılır.

Hava sporları turizminde ana faaliyet konusunu teşkil eden araçlar katılımcıların ilgilerine göre çeşitlilik arz etmektedir. Kültür ve Turizm Bakanlığı verilerine göre ülkemizde gerçekleştirilen hava sporları turizmi araçlarını şu şekilde siralamaktadır (www.kultur.gov.tr);

- Yamaç paraşütü

- Yelken (delta) Kanat

- Sicak Hava Balonu

- Mikrolayt

- Planör

- Model Uçak

- Paraşüt

Bahsi geçen araçlar ile ilgili yapılacak faaliyetler ve gerekli olan koşullar Tablo 5’Te verilmiştir. Tablo incelendiğinde sert hava akımının olmadığı dağlık alanların yoğunluğunun az olduğu destinasyonlarda söz konusu faaliyetlerden bir ya da bir kaçı yapılabilir. Bu faaliyetler bölgede gerçekleştirilen turizme de yapısal olarak katkı sağlayacaktır.

Misafire hedef destinasyonda sunulacak hava sporları faaliyetleri gibi ek imkânlar, turistik ürünü zenginleştireceği gibi konaklama sürelerini uzatıp misafirlerin seyahatten alacakları doyumu da arttıracaktır. Diğer yandan söz konusu ilave faaliyetler ile turizm harcamalarının da yerel halka yayılması söz konusu olacaktır. Bu duruma en güzel örnek, Kapadokya bölgesinde gerçekleştirilen sıcak hava balonu 
uçuşlarıdır. Söz konusu faaliyetler, turistik ürünü zenginleştirmenin yanı sıra, yeni turizm türlerini doğurmakta, bölge için ekstra bir cazibe unsuru olarak kendini göstermektedir. Diğer yandan bir sektör haline gelen bu faaliyetler ile turizm gelirleri bölge halkının büyük bir kısmının faydalanabileceği bir hale gelmiştir. Bu bağlamda hava sporları söz konusu faaliyetlerle ilgili uygun alt yapısı olan destinasyonlar için önemli bir fırsat yaratmaktadır. 
Tablo 5. Ülkemizde Turizm Kapsamında Gerçekleştirilen Hava Sporları Bilgileri

Hava Sporlarına Konu Olan Aracin;

\begin{tabular}{|c|c|c|c|c|}
\hline Türü & Tanımı & $\begin{array}{l}\text { Ülkemizde } \\
\text { Yapıldığı Bölgeler }\end{array}$ & Uçuş Dönemi & Gereksinimler \\
\hline $\begin{array}{l}\text { Yamaç } \\
\text { Paraşütü }\end{array}$ & $\begin{array}{l}\text { Sabit bir yapıya sahip olmayan, elde taşınabilen, tepeden koşarak veya } \\
\text { yerden vinç ile havalanan, pilotun kubbeye bağlı kontrol iplerini } \\
\text { çekmesiyle iki eksende kumanda edilebilen ve pilotun bacaklarının } \\
\text { enerjisi ile inebilen hava aracıdır. }\end{array}$ & $\begin{array}{l}\text { Muğla- Fethiye } \\
\text { Denizli- } \\
\text { Pamukkale } \\
\text { Ankara- Gölbaşı } \\
\text { Bolu-Abant } \\
\text { Kayseri } \\
\text { Eskişehir- İnönü }\end{array}$ & $\begin{array}{l}\text { Nisan - Ekim arası uçuşlar } \\
\text { için en güvenli } \\
\text { zamanlardır. }\end{array}$ & $\begin{array}{l}\text { Kalkış için hâkim yükseklik, iniş için } \\
\text { engelsiz alan. }\end{array}$ \\
\hline $\begin{array}{l}\text { Yelken } \\
\text { Kanat }\end{array}$ & $\begin{array}{l}\text { Elde taşınabilen, tepeden koşarak, yerden vinç veya motorlu yelken kanat } \\
\text { römorkunda havalanabilen pilot ağırlık merkezinin yerini değiştirmesiyle } \\
\text { iki eksende kumanda edilebilen ve pilotun bacaklarının enerjisiyle inebilen } \\
\text { sert bir ana yapıya sahip hava aracıdır. }\end{array}$ & $\begin{array}{l}\text { Muğla- Fethiye } \\
\text { Denizli- } \\
\text { Pamukkale } \\
\text { Ankara- Gölbaşı } \\
\text { Bolu-Abant } \\
\text { Kayseri } \\
\text { Eskişehir- İnönü }\end{array}$ & $\begin{array}{l}\text { Nisan - Ekim arası uçuşlar } \\
\text { için en güvenli } \\
\text { zamanlardır }\end{array}$ & $\begin{array}{l}\text { Kalkış için hâkim yükseklik, iniş için } \\
\text { engelsiz alan }\end{array}$ \\
\hline $\begin{array}{l}\text { Sicak } \\
\text { Hava } \\
\text { Balonu }\end{array}$ & $\begin{array}{l}\text { Isıtılmış hava ya da helyum gibi hafif bir gazla doldurulan, atmosferde } \\
\text { uçabilen, küre şeklinde insanlı hava aracıdır. }\end{array}$ & $\begin{array}{l}\text { Nevşehir, Denizli, } \\
\text { Samsun }\end{array}$ & $\begin{array}{l}\text { Hava koşularının } \\
\text { elverdiği her dönemde } \\
\text { gerçekleştirilir. }\end{array}$ & $\begin{array}{l}\text { İniş için en az 100mt'lik engelsiz ve düz } \\
\text { zemin. }\end{array}$ \\
\hline Mikrolayt & $\begin{array}{l}\text { Havadan ağır, hareket halinde iken havanın aerodinamik yapısı üzerine } \\
\text { etkisi ile havada dinamik olarak tutunabilen ve belirlenen limitlerde uçan } \\
\text { motorlu araçlarıdır. }\end{array}$ & $\begin{array}{l}\text { Şartlara Haiz } \\
\text { Bütün Bölgelerde }\end{array}$ & $\begin{array}{l}\text { Yağışsız ve stabil havaya } \\
\text { sahip zamanlar }\end{array}$ & $\begin{array}{l}\text { Kalkış ile inişte engelsiz orta ve üstü } \\
\text { sertlikte zemin }\end{array}$ \\
\hline Planör & $\begin{array}{l}\text { Uçuş esnasında sabit aerodinamik tepkimeler üreten yüzeyler sayesinde } \\
\text { kaldırma gücü oluşturabilen, havadan ağır motorsuz hava aracıdır. }\end{array}$ & Eskişehir & $\begin{array}{l}\text { Yağışsız ve stabil havaya } \\
\text { sahip zamanlar }\end{array}$ & $\begin{array}{l}\text { Kalkış ile inişte engelsiz orta ve üstü } \\
\text { sertlikte zemin. }\end{array}$ \\
\hline Paraşüt & $\begin{array}{l}\text { Yer çekiminin aksi yönünde, üzerine havanın yapmış olduğu etkileri } \\
\text { kullanan, katlanabilen, belirlenmiş bir yükseklikten atlayarak düşüş hızına } \\
\text { bağlı olarak ve havanın kaldırma prensibinden hareketle otomatik veya } \\
\text { isteğe bağlı açılan ve yer çekimine tabi olarak yere inilmesini sağlayan } \\
\text { kuşam tertibatı ve kubbeden oluşan bir hava indirme aracıdır. }\end{array}$ & $\begin{array}{l}\text { Ankara } \\
\text { Eskiş̧ehir } \\
\text { İzmir }\end{array}$ & $\begin{array}{l}\text { Yağışsız ve stabil havaya } \\
\text { sahip zamanlar }\end{array}$ & İnişte engelsiz, düz ve yumuşak zemin. \\
\hline
\end{tabular}

Kaynak: THK, 2012: 7-9; THK, 2015: 5-6; www.kultur.gov.tr den elde edilen bilgiler ile hazırlanmıştır. 
Hava sporları faaliyetlerine katılmak amacıyla yapılan seyahatlerin artışı ülkemizde olduğu gibi dünya genelinde de yükselme eğilimindedir. Kanada Turizm Bakanlığı adına hava sporları aktiviteleri katılımcıları üzerine yapılan bir araştırmada Amerika kıtasında 2006 yılından söz konusu faaliyetlere katılanların sayısı Tablo 6' da görülmektedir.

Tablo 6. 2006 Yılı Amerika Kıtasında Hava Sporları Turizmi Katılımcı İstatistikleri

\begin{tabular}{|c|c|c|c|}
\hline & $\begin{array}{c}\text { Hava Sporu } \\
\text { Katılımciları } \\
\text { Sayısı }\end{array}$ & $\begin{array}{c}\text { Seyahat Nedeni } \\
\text { Hava Sporu } \\
\text { Olanlar (\%) }\end{array}$ & $\begin{array}{c}\text { Amerika } \\
\text { Nüfusuna } \\
\text { Oranları (\%) }\end{array}$ \\
\hline Pazar Büyüklü̈̆̈̈ & 3.448 .184 & 1.115 .294 & 222.846 .268 \\
\hline $\begin{array}{l}\text { Adrenalin Yoğun Hava } \\
\text { Sporları (Tamamı) }\end{array}$ & 3.448 .184 & 32,5 & 1.3 \\
\hline Sicak Hava Balonu & 1.642 .626 & 47.0 & 0.7 \\
\hline Paraşüt & 715.225 & 38.0 & 0.3 \\
\hline Bungee Jumping & 715.071 & 25.0 & 0.3 \\
\hline Delta Kanat, Mikrolayt & 375.262 & 21.3 & 0.2 \\
\hline $\begin{array}{l}\text { Her Dört Aktivite } \\
\text { Grubuna Katılanlar }\end{array}$ & 48.422 & 8.8 & $0.1^{\prime}$ den az \\
\hline
\end{tabular}

Kaynak: TAMS, 2006: 3.

2006 y1lı içerisinde toplam 3.448.184 kişi seyahatleri sırasında hava sporları aktivitelerine katılmışlardır. Seyahatlerinin temel nedeni hava sporları aktivitelerine katılmak olanların sayısı 1.115.294 kişidir. Söz konusu sporlardan katılımın en yoğun olduğu dallar ise sıcak hava balonu ve paraşüttür. Görüldüğü üzere hava sporları turizmi katılımcıları azımsanmayacak sayıdadır.

İlgili çalışma (TAMS, 2006) verilerinde belirtilen bir diğer husus da söz konusu turizm çeşidi katılımcılarının profilidir. Hava sporları turizmi katılımcılarının profil incelendiğinde de hava sporları turizmi katılımcılarının demografik özellikleri bakımından da farklılık gösterdiği görülmektedir.

Tablo 6'da görüldüğü üzere 2006 yılında Amerika kıtasında hava sporları güdüsü ile seyahat eden ya da seyahatleri esnasında hava sporları deneyimi gerçekleştirenler genelde $25-44$ ile 45 ve üzeri yaş gruplarında toplanan turistlerden oluşmaktadır. Sıcak hava balonu katılımcıları ağırlıklı olarak 45 yaş ve üzeri bireylerden oluşmaktadır. Adrenalin içeren diğer hava sporları türleri katılımcıları 2534 yaş aralığında iken 35-44 yaş aralığındaki bireyler ise her spor türüne yatkın kişilerdir. 
Tablo 7. Hava Sporları Katılımcı Profili

\begin{tabular}{|c|c|c|}
\hline Gösterge & Değişken & Oran (\%) \\
\hline \multirow[t]{2}{*}{ Cinsiyet } & Erkek & 58,5 \\
\hline & Kadın & 41,5 \\
\hline \multirow[t]{4}{*}{ Yaş Aralığ1 } & $18-24$ yaş aralığ & 15,7 \\
\hline & 25-34 yaş aralığ & 25,5 \\
\hline & $35-44$ yaş aralığ & 14,4 \\
\hline & 45 ve üzeri & 44,7 \\
\hline \multirow[t]{2}{*}{ Medeni Hal } & Evli & 34,1 \\
\hline & Bekâr & 65,9 \\
\hline \multirow[t]{4}{*}{ Eğitim Durumu } & Orta Öğretim & 14,3 \\
\hline & Lise ve Dengi & 22,2 \\
\hline & Üniversite & 43,0 \\
\hline & Lisansüstü & 20,5 \\
\hline \multirow[t]{5}{*}{ Yıllık Ortalama Hane Geliri (\$) } & 20,000 ve alt1 & 8,4 \\
\hline & $20,000-59,999$ & 27,7 \\
\hline & $60,000-99,999$ & 22,9 \\
\hline & 100,000 ve üzeri & 29,9 \\
\hline & Beyan edilmemiş & 11,1 \\
\hline
\end{tabular}

Kaynak: TAMS, 2006: 4.

Hava sporları katılımcılarının eğitim durumu incelendiğinde ağırlıklı olarak üniversite mezunları olduğu görülmektedir. Diğer yandan lisansüstü eğitime sahip katılımcıların oranı da azımsanmayacak düzeydedir. Gelir düzeyleri incelendiğinde katılımcıların 1/3'ünün yıllık ortalama geliri 100,000 dolar ve üzerindedir. Bu durum hava sporları turizmine katılanların harcama eğilimlerinin yüksek olabileceğini göstermektedir.

Hava sporları faaliyetlerinin turizm destinasyonlarına uygun olması ile ilgili bir başka nokta ise hava sporları türlerinin doğaya karşı olan olumsuz etkilerinin diğer spor turizmi çeşitlerinden daha az olmasıdır. Hava sporları turizmi doğal çevreye saygilı bir turizm türüdür.

Koçak ve Balcı (2010), çalışmalarında doğal alan kullanımının çevre üzerindeki etkilerini belirlemek için aşağıdaki tabloda yer alan kriterleri kullanmışlardır. Tabloda spor çeşitlerinin doğaya verebileceği zararlar görülmektedir. Hava sporları aktivitelerinin olası etkileri; gürültü, hava kirliliği ve havada yaşayan türlerin rahatsız edilmesi olarak ifade edilmiştir. Bununla birlikte tabloda belirtilen hava kirliliği ya da gürültü gibi riskler ağır motorlu hava araçlarının kullanılması halinde ortaya çıkan bir durumdur. Hava sporları turizminde genelde kullanılan araçların hafif motorlu ya da motorsuz türler olması emisyon oranlarının minimum ya da sıfır olmasına neden olmaktadır. Diğer yandan söz konusu tipteki araçlar gürültü kirliliğini de çok fazla neden olan türler değildir. Türlerin (fauna elemanları) rahatsız edilmesi noktasında ise hava sporlarının gerçekleştirildiği rotalarda kanatlı canlıların bulunması uçuş emniyetini düşürecektir. Bu bağlamda uçuşlar planlama aşamasında türlerden uzak 
noktalarda planlanarak uçuş emniyeti sağlanmalı ve doğaya verilecek olan zarar minimuma indirilmelidir.

Tablo 8. Doğal Alan Kullanımının Çevre Üzerindeki Etkileri

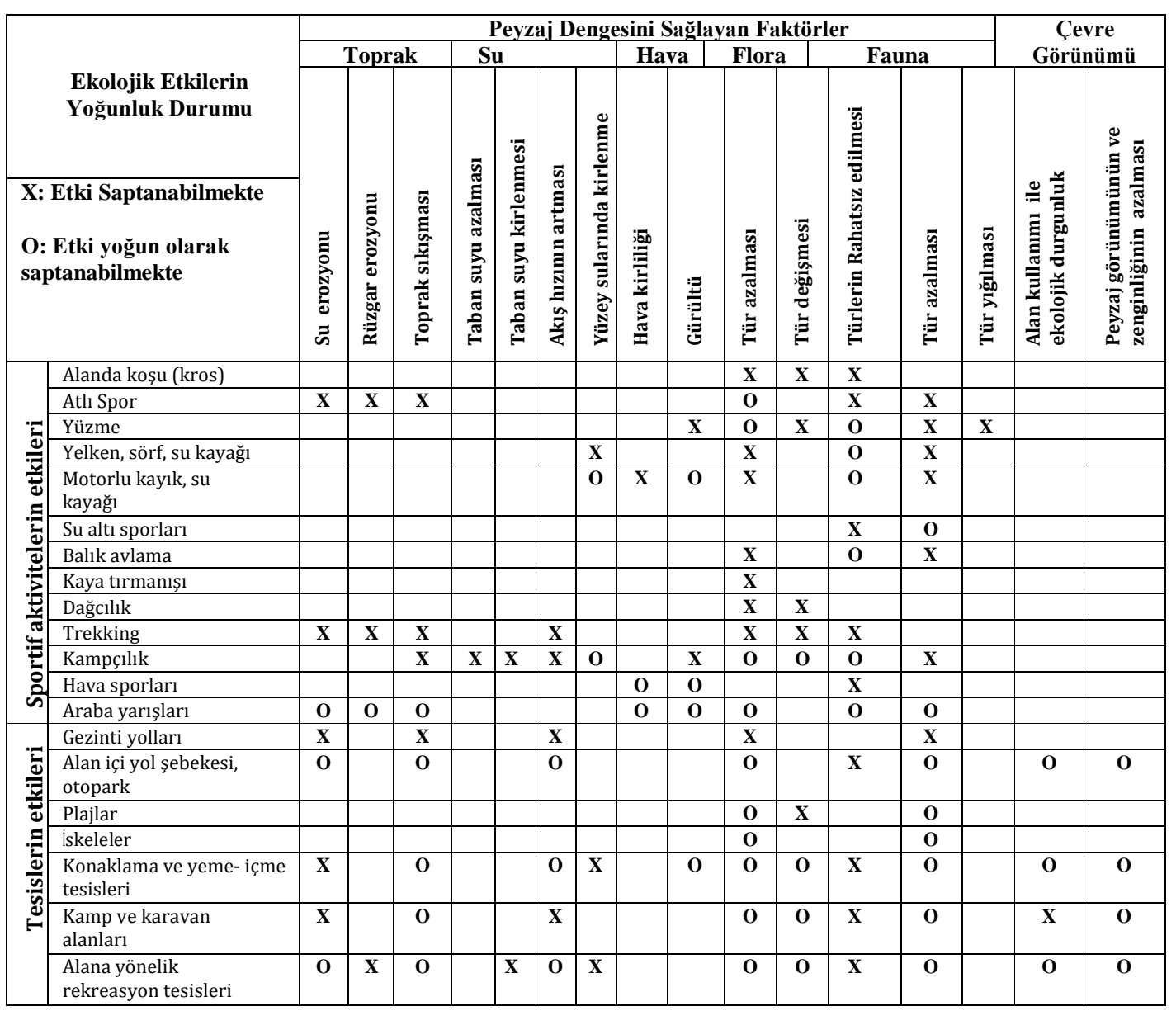

Kaynak: Koçak ve Balcı, 2010: 217.

Genel olarak özetlenecek olursa, spor turizmi çeşitlerinden olan hava sporları turizmi gerek dünya turizm piyasasında gerekse ülkemiz turizm piyasasında gelişen bir turizm çeşidi olarak ortaya çıkmaktadır. Uygun altyapıya sahip destinasyonlarda gerçekleştirilecek hava sporları faaliyetleri gerek doğrudan gerekse dolaylı olarak ziyaretçilerde seyahat motivasyonu oluşturacaktır. Bu ise ilgili turizm bölgesinde konaklama sürelerini uzatacak, gelirleri arttıracak ve ekstra bir cazibe unsuru olarak turizme katkıda bulunacaktır. Hava sporları turizmi katılımcı profili incelendiğinde eğitim seviyesi ve gelir düzeyi yüksek kişilerden oluştuğu görülmektedir. Bu durum hedef destinasyonda gerek turizm harcamalarını, gerekse kültürel etkileri olumlu yönde etkileyecektir. Diğer yandan hava sporları turizmi turistik ürünü çeşitlendirerek farklı turizm türlerini destinasyonda uygulanmasını sağlayacaktır (örn: hava fotoğrafçılı̆̆ı faaliyetleri, hava sporları müsabakaları). Son olarak çevreye saygılı 
faaliyetler olması nedeniyle hava sporları sürdürülebilir turizme katkıda bulunan bir turizm türüdür.

Yukarıda ifade edilen tüm bu açılardan incelendiğinde hava sporları turizminin turistik ürün çeşidinin zayıf, geceleme sayıları az olan ancak hava sporları açısından uygun alt yapı imkânlarına sahip turizm destinasyonlarında uygulanması doğrudan bölge turizmine dolaylı olarak da bölge ekonomisine katkıda bulunacaktır.

\section{SAFRANBOLU'NUN HAVA SPORLARI TURIZMI POTANSIYYELI}

Kültür turizmi bakımından zengin bir potansiyele sahip olan Safranbolu destinasyonu özellikle eski yerleşimin yoğun olduğu "Çarşı" mevkii ile öne çıkmaktadır. Eski Hükümet Binası, Saat Kulesi, Eski Cephane Binası, Eski Hapishane Binası, tarihi konaklar, İzzet Mehmet Paşa, Köprülü Mehmet Paşa, Kazdağlıŏlu, Dağdelen, Kaçak, Mescit Camileri, Cinci Hanı ve Hamamı bu bölgede şehrin görülmeye değer tarihi yapılarıdır. İki anıt mezarın da bulunduğu Hıdırlık Tepesi, açık hava namazgâhı olarak kullanılmış olup kentin seyir terasıdır (Diker ve Çetinkaya, 2016: 118-119).

Safranbolu,1975 yılında o dönemki adıyla Yüksek Anıtlar Kurulu olan Kültür ve Tabiat Varlıklarını Koruma Yüksek Kurulu tarafından " Kentsel Sit" alanı ilan edilmiştir. Bu tarihten itibaren kültür turizmi destinasyonu olarak önem kazanmaya başlayan kentin1994 yılında UNESCO tarafından “Dünya Miras Kenti" olarak ilan edilmesi ile turizm hareketleri yukarı doğru bir ivme kazanmıştır. Günümüzde de bu ivme düşük oranda da olsa devam etmektedir. Karabük İl Kültür ve Turizm Müdürlüğü verilerine göre 2015 yılında Safranbolu'yu 109.015 kişi ziyaret etmiştir (Bkz. Tablo 9). 2015 yılında . 190.111'i yerli, ve 53.966'i yabanci turist gecelemeleri olmak üzere toplamgeceleme sayısı 244.107 olarak gerçekleşmiştir (Bkz. Tablo 10).

Tablo 9. 2015 Yılı Safranbolu Ziyaretçi Sayıları

\begin{tabular}{|l|l|}
\hline \multicolumn{2}{|l|}{} \\
\hline Yerli Turistler & 61.347 \\
\hline Yabanci Turistler & 47.668 \\
\hline Toplam & 109.015 \\
\hline
\end{tabular}

Kaynak: Karabük İl Kültür ve Turizm Müdürlüğü

Tablo 10. 2015 Y11 Safranbolu Konaklama Sayıları

\begin{tabular}{|l|l|}
\hline \multicolumn{2}{|l|}{} \\
\hline Yerli Turistler & 190.111 \\
\hline Yabancı Turistler & 53.966 \\
\hline Toplam & 244.107 \\
\hline
\end{tabular}

Kaynak: Karabük İl Kültür ve Turizm Müdürlüğü

Toplam gecelemenin ziyaretçi sayısına oranı 2 olarak tespit edilmiştir. $\mathrm{Bu}$ durum Safranbolu turizm destinasyonunda ziyaretçilerin ortalama kalış süresinin 2 gece olduğunu göstermektedir. Yerli ziyaretçiler için bu ortalama kalış süresi 3 gece iken yabancı ziyaretçiler için bu rakam 1 olarak tespit edilmiştir. Bu süre bir turistik 
destinasyon için yetersiz olmasının yanında turizm gelirlerini de olumsuz etkilemektedir.

Türker (2006), Safranbolu turizminin temel sorunlarından birisinin ziyaretçilerin konaklama sürelerinin 1-2 gecelemeyi geçmemesi olduğunu ifade etmektedir. Bunun en önemli nedenini turistik ürünün tek tip olması, ilçede turistik ürün çeşitlendirilmesine gidilememesi ve yeterli turistik aktivite yaratılamaması olduğunu belirtmektedir (Türker, 2006: 9). Bu bağlamda daha öncede belirtildiği gibi hava sporları turizmi Safranbolu destinasyonu için turistik ürüne çeşitlilik, destinasyona cazibe katarken konaklama sürelerinin uzamasına da yardımcı olabilir.

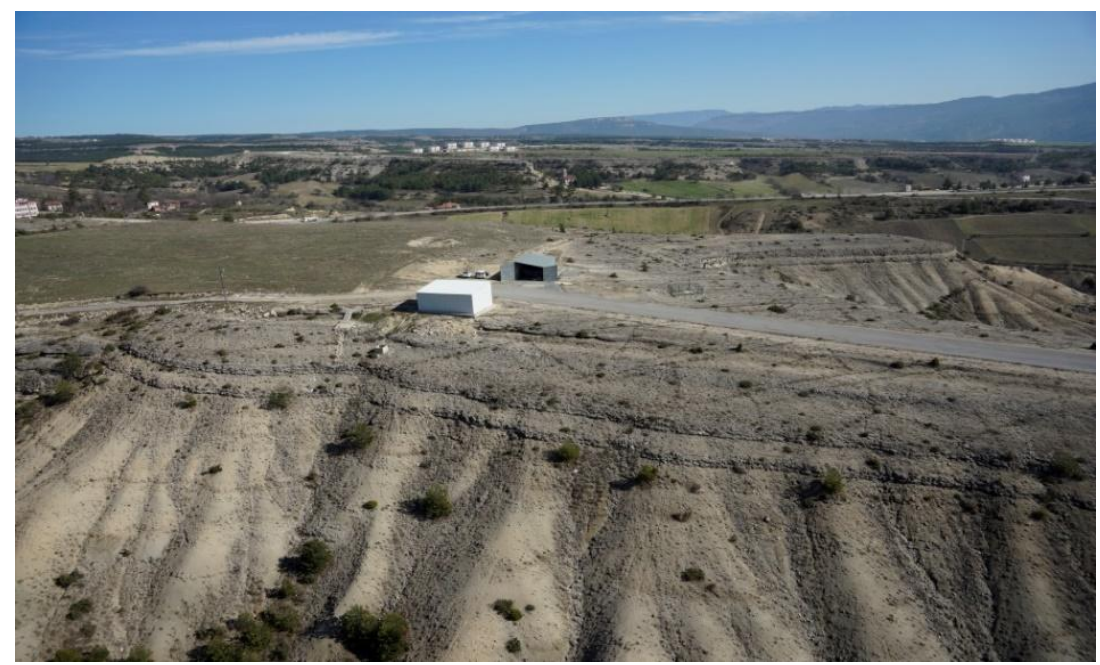

Şekil 1. Kirkille Mevkii Hafif Motorlu Hava Aracı Pisti

Safranbolu ilçesinde Bartın karayolu 4. Kilometresinde bulunan mevkide bulunan $41^{\circ} 15^{\prime} 06.95^{\prime \prime} \mathrm{K}, 32^{\circ} 41^{\prime} 37.56$ "D koordinatlarında 513 metre yükseklikte bulunan ve şekil 1'de belirtilen alan Kıbrıs merkezli Uluslararası Havacılık Akademisi tarafından pist olarak kullanılmakta ve 2010 yılından bugüne hafif motorlu hava araçlarından mikrolayt eğitimleri verilmektedir. Pist özellikleri hava araçlarından mikrolayt, radyo kontrollü uçak için uygunluk arz etmektedir. 


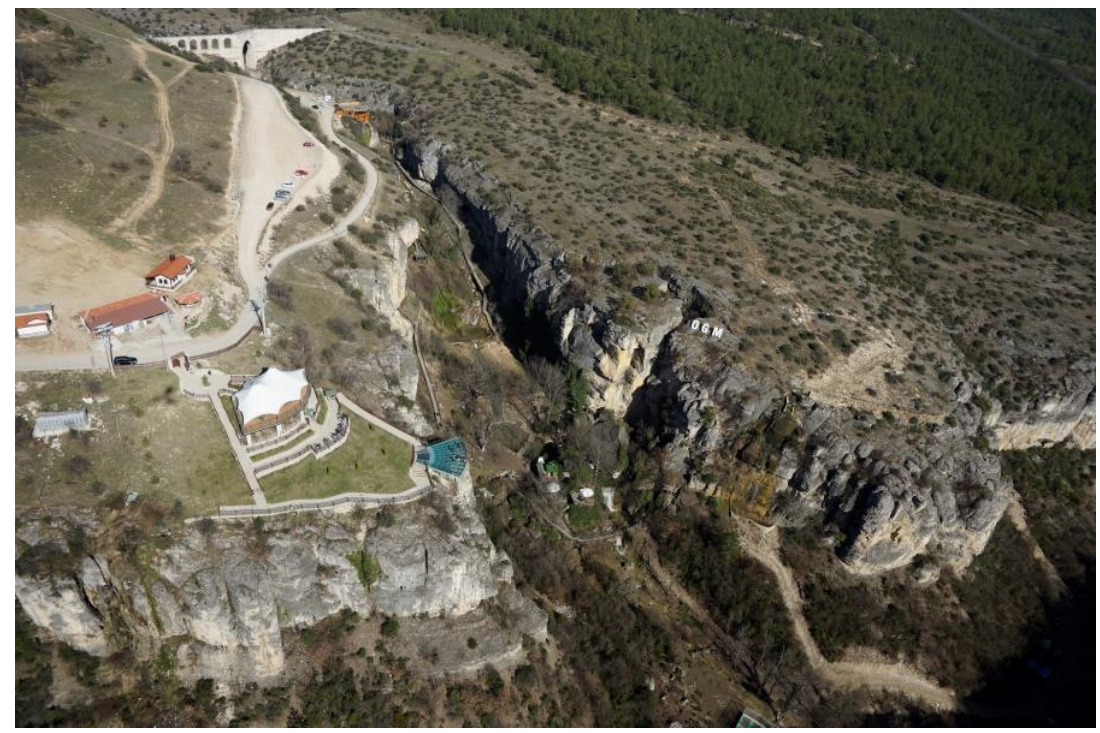

Şekil 2. Kuşbakışı Safranbolu Cam Teras ile İncekaya Su Kemeri

Söz konusu araçlar ile Safranbolu destinasyonunda gerçekleştirilebilecek aktiviteler şu şekilde sıralanabilir;

Bir uçuş sorumlusu (pilot) ve bir yolcu ile seyahat edebilen mikrolayt ile Kirkilli uçuş pistinden yapılacak kalkış ile 5, 10, 15 ve 20'şer dakikalık parkurlar ile turlar düzenlenebilir. Bu parkurlarda Safranbolu Çarşı mevkii, Tokatlı Kanyonu, İncekaya Su Kemeri, Bulak bölgelerine yakın mesafe ve uzak mesafe uçuşlar gerçekleştirilebilir. Bu uçuşlarda Safranbolu doğasının yeşil ve gri hâkim renginin ahengi ile Çarşı mevkiindeki mimarinin büyüsüne yönelik hava fotoğrafçılığı, gözlemcilik gibi farklı özel ilgili faaliyetleri de gerçekleştirilebilir.

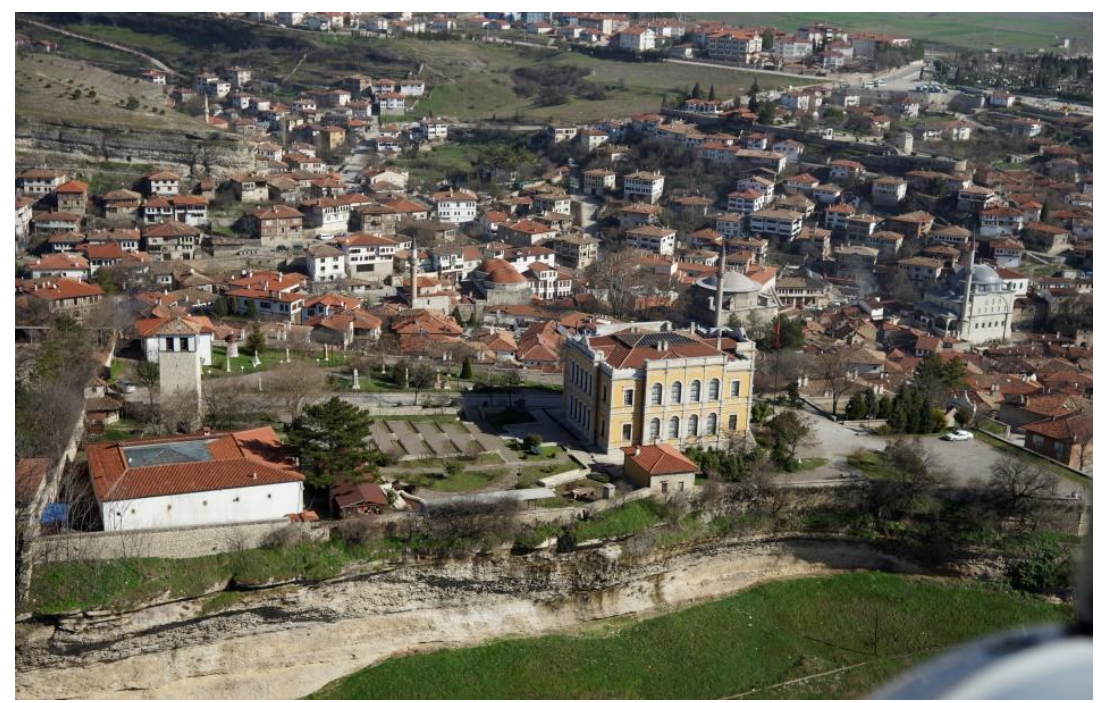

Şekil 3. Kuşbakışı Eski Hükümet Konağ1

İlgili uçuş pisti, günümüzde popülerliği gitgide artan, bazı türleri drone ya da insansız hava aracı olarak da adlandırılan radyo kontrollü uçakların uçuşları için de 
uygundur. Söz konusu araçlar hava fotoğrafçılığı, tür gözlemciliği ve müsabakalar için de kullanilmaktadir.

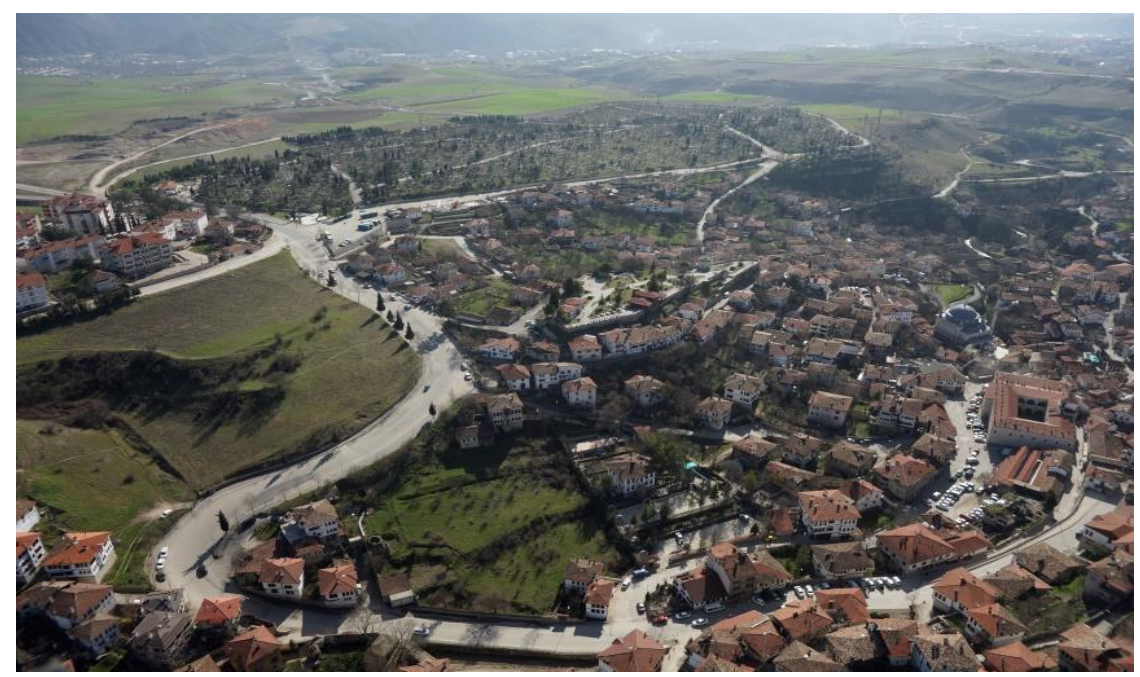

Şekil 4. Safranbolu Çarşı Mevkii

Safranbolu destinasyonu için uçuşa elverişli bir başka alan ise Toprakcuma Navsaklar Köyü kırsalıdır. Söz konusu bölgede uçuşa müsait 400 ile 600 metre arasında hâkim tepeler mevcuttur. İlgili bölgelerde, delta kanat ve yamaç paraşütü uçuşları gerçekleştirilebilir. Bölgede esen rüzgârın, denizden dik gelmesi nedeniyle bölge sıcak hava balonu için uygun değildir. Fakat diğer hava araçları için bölge uygun hava koşullarına sahiptir.

Sonuç olarak Safranbolu turizm destinasyonu hava sporları türlerinin büyük bir çoğunluğu için uygun hava koşullarına ve altyapıya sahiptir. Bu aktivitelerin turistik ürün kapsamında değerlendirilmesi, paket turlara eklenmesi, düzenlenecek çeşitli sportif etkinliklerle destinasyonun turizm payının artırılması, geceleme sayısının uzaması gibi pozitif sonuçlar doğuracaktır.

\section{SONUÇ}

Hava sporları turizmi hava koşulları ve alt yapısı uygun olan turistik destinasyonlarda turistik ürünlerin zenginleşmesine katkıda bulunur. Bu durum dolaylı olarak konaklama sürelerinin uzamasına ve turizm gelirlerinin artmasına neden olur. $\mathrm{Bu}$ bağlamda konaklama sürelerinin kisa olduğu, turistik ürün çeşitliliğinin zayıf olduğu Safranbolu destinasyonu içinde hava sporları turizmi turizm sektörünün gelişmesini sağlayıcı önemli bir fırsat olarak değerlendirilebilir.

Kirkilli mevkii, Toprakcuma Navsaklar Köyü kırsalı mikrolayt, yamaç paraşütü, radyo kontrollü uçak ve delta kanat uçuşları için uygun alanlarıdır. Söz konusu uçuş faaliyetlerinin bölgeye düzenlenen tur programlarına dahil edilmesi, destinasyonun bu tür faaliyetler için uygunluğu ile ilgili tanıtımların yapılması ve bu tip faaliyetler çerçevesinde düzenlenen organizasyonlara ev sahipliği yapılması ile söz konusu faaliyetler turistik ürün içerisine girecek böylece bir cazibe oluşturulacaktır. Bu ise uzun vadede gerek ekonomik gerekse sektörel faydalar sağlayacaktır. Gelecekte 
yapılacak çalışmalarda söz konusu faaliyetlerin Safranbolu'nun da içerisinde bulunduğu Batı Karadeniz Bölümündeki diğer destinasyonlar için de uygun olup olmadığı araştırılmalı ve uygun alanlar bulunması halinde tüm bölgede entegre bir aktivite haline gelmesi yönünde çalışmalar yapılmalıdır.

\section{KAYNAKÇA}

Albayrak, A. (2013). Alternatif Turizm, Detay Yayıncllık, Ankara.

Diker, O., Çetinkaya, A. (2016). Erişilebilir Turizm Açısından Safranbolu Turizm Destinasyonun Uygunluğunun Değerlendirilmesi, Karabük Üniversitesi Sosyal Bilimler Enstitüsü Dergisi Özel Sayı, 2, s. 111-125.

Doğan, Z. (2004). Turizmin Sosyo- Kültürel Temelleri, Detay Yayıncılık, Ankara.

Gibson, J. H. (1998). Active Sport Tourism: Who Participates?, Leisure Studies, 17:2, s. 155-170.

Gibson, J. H. (1998). Sport Tourism: A Critical Analysis of Research, Sport Management Review, 1, s. 45-76.

Gnoth, J. (1997). Tourism Motivation and Expectation Formation, Annals of Tourism Research, Vol.21, No.2, s. 283-304.

Hinch, T. D., Higman, J. E. S. (2001). SportTourism: A Framework for Research, International Journal of Tourism Research,3 ,s. 45-58.

Karabük İl Kültür ve Turizm Müdürlüğü Turizm İstatistikleri, 2015.

Koçak, F., Balcı, V. (2010). Doğada Yapılan Sportif Etkinliklerde Çevresel Sürdürülebilirlik, Ankara Üniversitesi Çevrebilimleri Dergisi, 2,2 s. 213-222.

Koçan, N. (2007). Geleneksel Sporlarımızdan Ciritin Rekreasyonel Amacı ile Günümüze Uyarlanması, Spor Yönetimi ve Bilgi Teknolojileri Dergisi, Cilt: 2, Sayı: 1, s. 1306-4371.

Kurtzman, J. (2005). SportTourismCategories, Journal of Sport\&Tourism, 10: 1, s. 15-20.

Kültür ve Turizm Bakanlığı (2015). www.kultur.gov.tr

Öztürk, Y., Yazıcıoğlu, İ. (2002). Gelişmekte Olan Ülkeler İçin Alternatif Turizm Faaliyetleri Üzerine Teorik Bir Çalışma, Gazi Üniversitesi Ticaret ve Turizm Eğitim Fakültesi Dergisi, 2, s. 183-195.

Pigeassou, C. (2004). Contribution to the Definition of Sport Tourism, Journal of Sport\&Tourism, 9: 3, s. 287-289.

Ritchie, B., Adair, D. (2002). The Growing Recognition of Sport Tourism, Current Issues in Tourism, 5: 1, s. 1-6.

Ross, D. S. (2001). Developing Sports Tourism An e-Guide for Destination Marketers and Sports Events Planners, National Laboratory for Tourism and e-Commerce, University of Illinois at Urbana-Champaign.

TAMS (2006). U.S. Activity Profile: Participating in Extreme Air Sports, Library and Archives Canada Cataloguing in Publication, Canada.

Türk Hava Kurumu (THK) Genel Başkanlığı (2012). Gösteriler Yönergesi, Ankara.

Türk Hava Kurumu (THK) Genel Başkanlığı (2015). Planör Uçuş Eğitim Okulu Uçuş ve Eğitim Yönergesi, Ankara. 
O. Diker, A. Çetinkaya, A. Cinkara / Karabük Üniversitesi Sosyal Bilimler Enstitüsü Dergisi, 2016, 6 (1), 84-100

Türker, N. (2006). Safranbolu'da Turizm: Turizmin Gelişmesi, Turistik Talebin Yapısı, Sorunlar, Çözüm Önerileri ve Gelecekten Beklentiler, Zamanlık, Safranbolu.

Türkiye Seyahat Acentacıları Birliği (TÜRSAB) (2015). Spor Turizmi Raporu, Ankara.

Yavaş, Ö. (2005). Sporun Ekonomi İçindeki Yeri ve Spor Pazarlama: Üç Büyük Spor Kulübünde Uygulamalı Bir Araştırma, Yayınlanmamış Yüksek Lisans Tezi, Trakya Üniversitesi Sosyal Bilimler Enstitüsü, Edirne. 